\title{
Histological changes in skin and gill of fresh water EUS infected fish Channa punctatus
}

\author{
Laharia Reena ${ }^{1}$ and Patel Paresh ${ }^{2}$ 政
}

Received: 08.03.2020

Revised: 05.04.2020

Accepted: 17.04.2020

\begin{abstract}
Histopathology is an important diseases diagnostic tool. Penetration into the host is the first step for a microbial agent to mutiply and invade the vital organs of its host. Like all animals fishes suffers from environmental, stress, which is followed by pathogenic attacks and parasitic afflictions causing Epizootic Ulcerative syndrome (EUS). Histological investigations of tissues of EUS infected fish Channa punctatus showed an eroded epidermis, necrosis of skeletal muscles and intense granulomatous inflammation, infiltration of mixed inflammatory cells in muscular as well as submuscular layers of the skin. Also a characteristic focal grannular granuloma in the gill lamellae was noticed. The electron microscopic observations, of the tissue cells of the fishe showed viruses like Parvovirus even at a red spot stage. Thus, it can be said that Viruses being crystalline in nature have cellular penetrating power \& the EUS infection follows the phyllogenetic evolution in life in true sense i.e. RNA virus followed by Bacterial cell and then Fungus. Thus, the presence of EUS in Channa punctatus is confirmed histologically.
\end{abstract}

Key words: Channa, Epizootic Ulcerative syndrome, Fungus, Histology, Parvovirus.

\section{Introduction}

A body of water with low $\mathrm{pH}$ has been documented in other outbreaks as a significant predisposing factor for EUS outbreaks (Sammut et al., 1996; Baldock et al., 2005; Choongo et al., 2009). Release of pollutants in the nature are affecting the basic environmental parameters like temperature, salinity, DO and $\mathrm{pH}$ affecting the protective mucus layer of the fishes making them vulnerable to the attack of virus followed by bacterial and fungal infection. Histopathological changes would be expected in organ, when the gross clinical and pathological signs of this type of disease occur (Vogelbein et al., 2001). Bacterial colonies observed in tissues are a proof of the presence of bacterial (Lio-Po et al., 1998), fungal (Lio-Po et al., 1998) and viral (Kanchankhan, 1996) infections. Kane et al., (2000) carried out the etiologies, observations and reporting of eustuarine fish fin lesions and histologically observed that the lesion demonstrated a marked chronic inflammatory infilterate and granulomas in

Author's Address
${ }^{1}$ Department of Zoology, Brijlal Biyani Science College,
Amravati-444602
${ }^{2}$ Department of Zoology, Lokmanya Tilak Mahavidyalaya,
Wani-445304

E-mail.: rtn.paresh@gmail.com response to fungal hyphae throughout large areas of necrotic muscle tissue and also observed Gramnegative rod-shaped bacteria in the lesions, a common finding in ulcers of aquatic organisms. Fish showing sores and ulcers referable to EUS were reported in the Equateur Province of the Democratic Republic of the Congo in December 2014, with a record of heavy fish mortalities. The present investigation is aimed to the identification of EUS through, histopathological observations of fresh water fish Channa punctatus.

The critical gross pathology was represented by cutaneous lesions fitting the case definition of EUS - red spots, erosions, ulcers and wounds. Skin ablation is thought to facilitate attraction of and infection by zoospores of $A$. invadans (Songe et al., 2012). The presence of fungal hyphae was demonstrated in the epidermis of some early, stages of infected fish from India (Viswanath et al., 1997). Kanchanakhan et al., (1998) achieved virus isolations from 3 epizootics in Thailand in 19931994 epizootic, 9 rhabdoviruses from EUS snakehead (Channa striata), three-spot gourami (Trichogaster trichopterus). And another 9 rhabdoviruses from 11 tissue extracts from affected snakehead collected in the 1995-1996 outbreak. 
Results of their study suggested that the viruses, especially rhabdovirus, are readily isolated from diseased fishes during the early period of an outbreak, and that they may have a significant role in a complex of etiological agents of EUS. Histopathological changes might be the concurrent effect of both the fungal pathogen (Aphanomyces) and the bacteria A. hydrophila. EUS diseases of many fishes were found to be caused by both the above pathogens by many authors in different fishes (Hasan et al 2008)

\section{Material and Methods}

The present study was carried out by collecting the suspected diseased fish from near by EUS prone water bodies (Wadali and Malkhed lakes) with the help of fishermen and were brought to the laboratory and maintained in glass aquaria for a week-to study the type of infection. The healthy fish weighing about $25 \mathrm{gm}$ and of approximately equal length were brought to the laboratory and kept in aquarium containing 75 litre of water and were acclimatized for 15 days. They were regularly fed on pellet feed and $25 \%$ water of the aquarium was also regularly changed at an interval of 7 days to maintain the water quality. 10 fishes were kept in one aquarium each.

\section{Experimental set up: -}

The experiment was carried out on six sets of 10 fishes in each group as below:

Group I : -Consisting of control (Healthy) fish (10, Channa punctatus).

Group II :- Consisting of Naturally EUS affected fish (10, Channas punctatus).

Group III :- Consisting of artificially infected fishes injected with $0.2 \mathrm{ml}$ homogenate of ulcerated skin tissue from diseased Channa punctatus (10, Channa punctatus).

\section{Suspension preparation:}

The tissue suspension of ulcerated skin tissue was prepared in sterile fish saline $(0.3 \%)$. A tissue (500 $\mathrm{mg}$ ) homogenate was prepared by taking affected or ulcerated skin in fish saline $(5 \mathrm{ml})$.

\section{Histological studies:}

The tissues like liver, gill, skin and kidney of EUS affected fishes (Channa punctatus) were dissected out, washed with saline water to remove adhering particals and blood stains and then fixed in Bouin's fixative for 16 to $20 \mathrm{hrs}$. Then the tissues were washed thoroughly with water, dehydrated with graded series of alcohol and embeded in paraffin wax and sections were cut at 4 to 5 microns. The sections were processed and stained with Haematoxylin-Eosin by standard methods as described by Weissman (1972).

\section{Electron microscopical studies for detection of viral infection:}

Specimen Preparation for TEM:

The tissues liver, kidney, skin and gills were dissected out aseptically in the laboratory, from the EUS affected fishes, trimmed to size $1.0-1.5 \mathrm{~mm}$ thick and fixed into a fixative containing 2.5\% Glutaraldehyde and 2\% paraformaldehyde, made in $0.1 \mathrm{M}$ sodium phosphate buffer $(\mathrm{pH} 7.4)$ for 6-12 hrs at $40 \mathrm{C}$ for $24 \mathrm{hrs}$. After fixation, the specimens were sent for detection of Viral infections, at AIIMS, New Delhi, where the ultra-thin sections were visualized under transmission electron microscope at different magnifications and photographed.

\section{Results and Discussion}

A general survey of Amravati fish market was carried, which revealed that most of the EUS affected fishes were brought by the fisherman from Wadali and Malkhed lakes. So, they were procurred from Wadali and Malkhed lakes during September to January months of 2004 to 2006.

All EUS affected fishes exhibited three distinct stages during the EUS infection (Table 1).

Stage - I - Red spot is seen

Stage - II - Red ring with a white

patch in the centre

Stage - III - The area of red ring

became necrosed with puffy appearence

with ulcer and haemorrhage. Multiple ulcers were seen on the body in advanced stage.

The healthy fishes (Fig: 1) were administered with the ulcerated tissue from the naturally EUS affected fish (Fig: 2) and were studied after 7, 14 and 21 days of challenge infection. These fishes also showed the three stages of the disease. In artificially EUS infected fishes a red spot was developed after 7 days of challenge inoculation and later on after 12-14 days a red ring was seen with 
loss of scales. Then after 20-24 days, the tissue exposed showing puffy appearance (Fig: 3 to 5). within the ring was totally degraded with muscles

Table: 1. External features shown by naturally EUS affected and artificially EUS infected fishes (Channa punctatus)

\section{Stage I}

Stage II

Stage III

Red spots on the body surface were seen.No discolouration as such on the skin surface or on the skin around the red spot was seen.
The Red spots turned into lesions which were around $1 \mathrm{~cm}$ in diameter, They appeared to be raised and circular in shape and the body surface area showed discolouration. At this stage the shin was intact and the scales were loosely attached.
The lesions formed showed the advanced stage of necrosis . They appeared to be circular extending deep into the skeletal musculature. Large haemarragic and necrotic ulcers were formed along with new emerging red spots seen on various parts of the body. At this stage the epidermis and scales were completely lost along with loss of dermis at the site of ulcer.

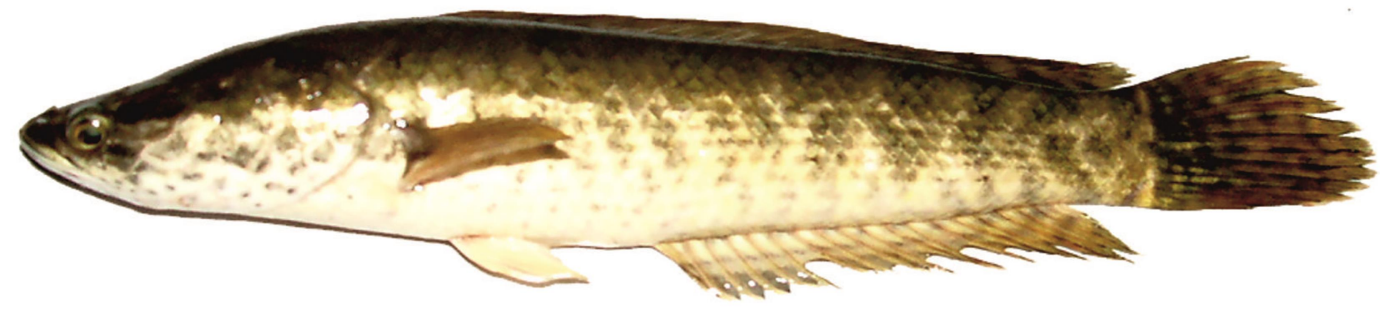

Fig :1, Control healthy Channa punctatus

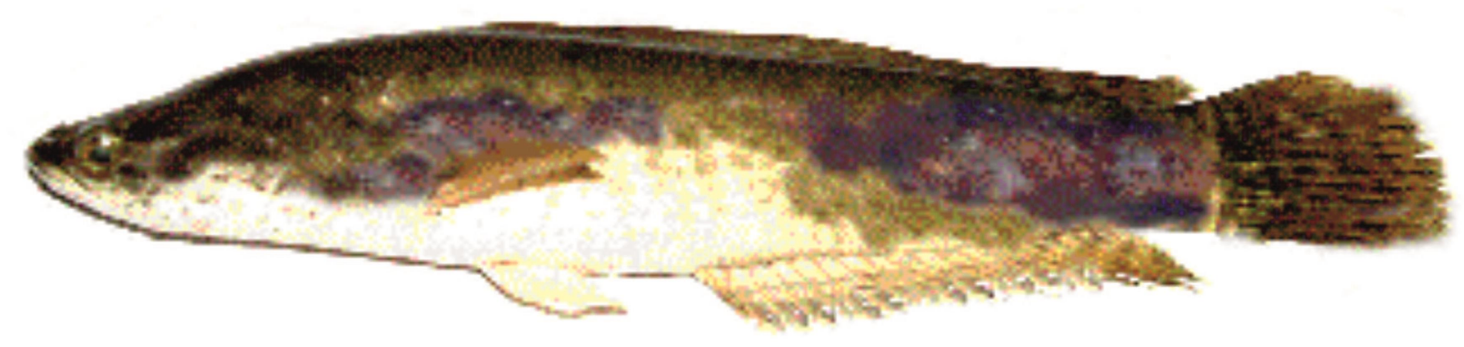

Fig :2, Naturally EUS affected Channa punctatus. 


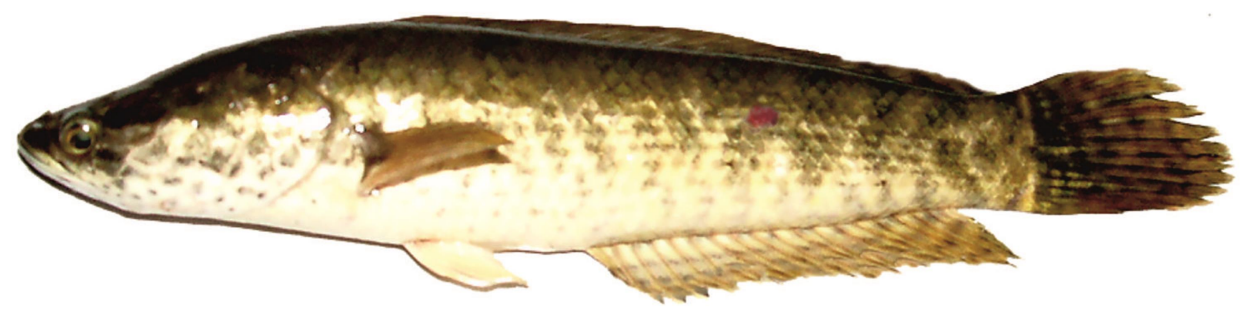

Fig : 3, Channa punctatus showing formation of red spot after 7 days.

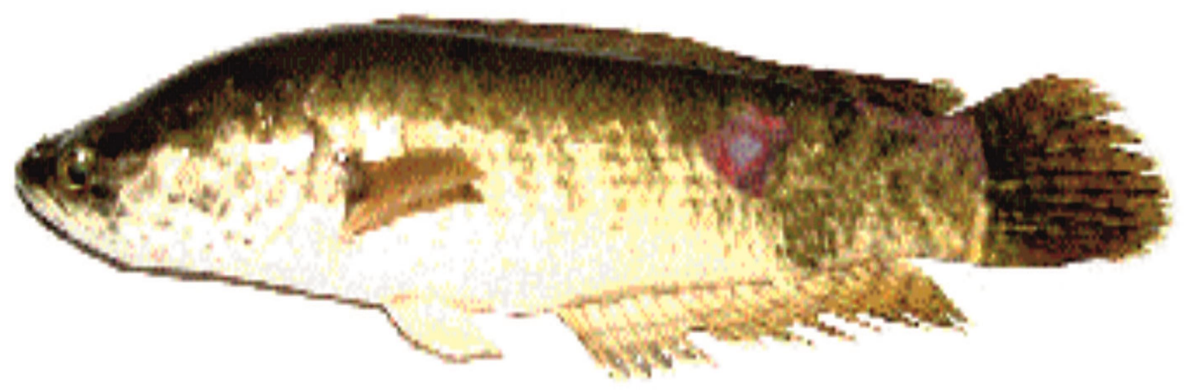

Fig : 4, Channa punctatus showing formation of red ring after 14 days.

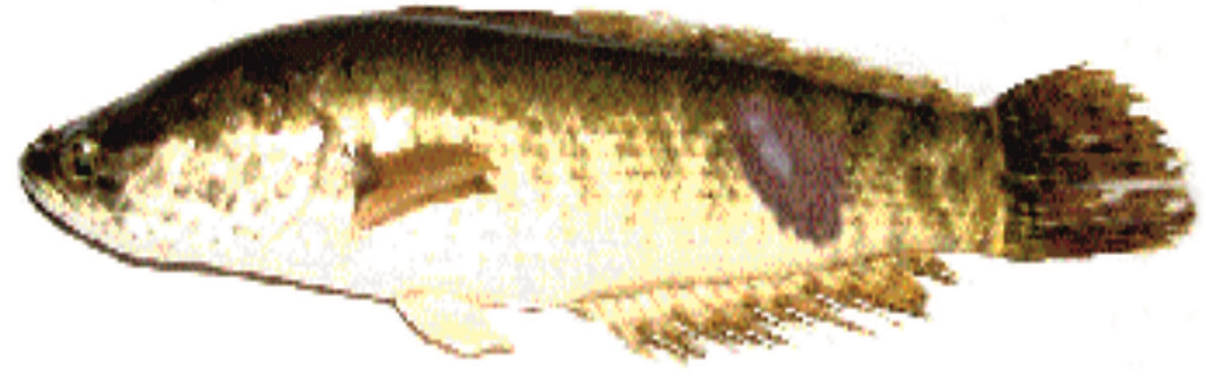

Fig 5, Channa punctatus showing ulcer formation after 21 days

Histopathological changes in skin:

Non-infected healthy control fishes exhibited an intact epidermis comprising stratified squamous epithelium 10-15 cells thick (Fig: 6). In contrast, infected Channa consistently exhibited widespreadpartial to complete loss of the epidermal layer of the skin (Fig: 7). After 21 days of infection, the fishes showed eroded epidermis over much of the infected regions (Fig:.8). Histologically the lesions are characterized by the presence of highly invasive, aseptate fungal hyphae penetrating deeply into the body muscles. Necrosis of skeletal muscles 
and intense granulomatous inflammation directed at the fungus were the prominent features of lesions seen in the V.S. of skin (Fig: 8).

\section{Histopathological changes in liver:}

The hepatic parenchyma is made of hepatocytes spread out as anastomotic cords arranged in two cellular layers and surrounded by sinusoids (Fig: 9 ). The bile ducts are usually found near the portal vein and they are lined by simple cuboidal epithelium. In EUS infected fishes, focal necrosis was seen in the liver with vacuolation of the hepatocytes; congestion and haemorrhages (Fig:10). The hepatic cells appeared shrinked with fungal infiltration (Fig: 11).

\section{Histopathological changes in gills:}

In Comparison to the gill lamellae of healthy Channa punctatus (Fig:12), The gill lamellae of the EUS infected Channa punctatus showed a well developed encapsulated granulomas around necrotic area is observed, which appeared nodular with characteristic focal (tubercles) granulomas. These are composed of a diffuse distribution of reticuloendothelial cells and macrophages with
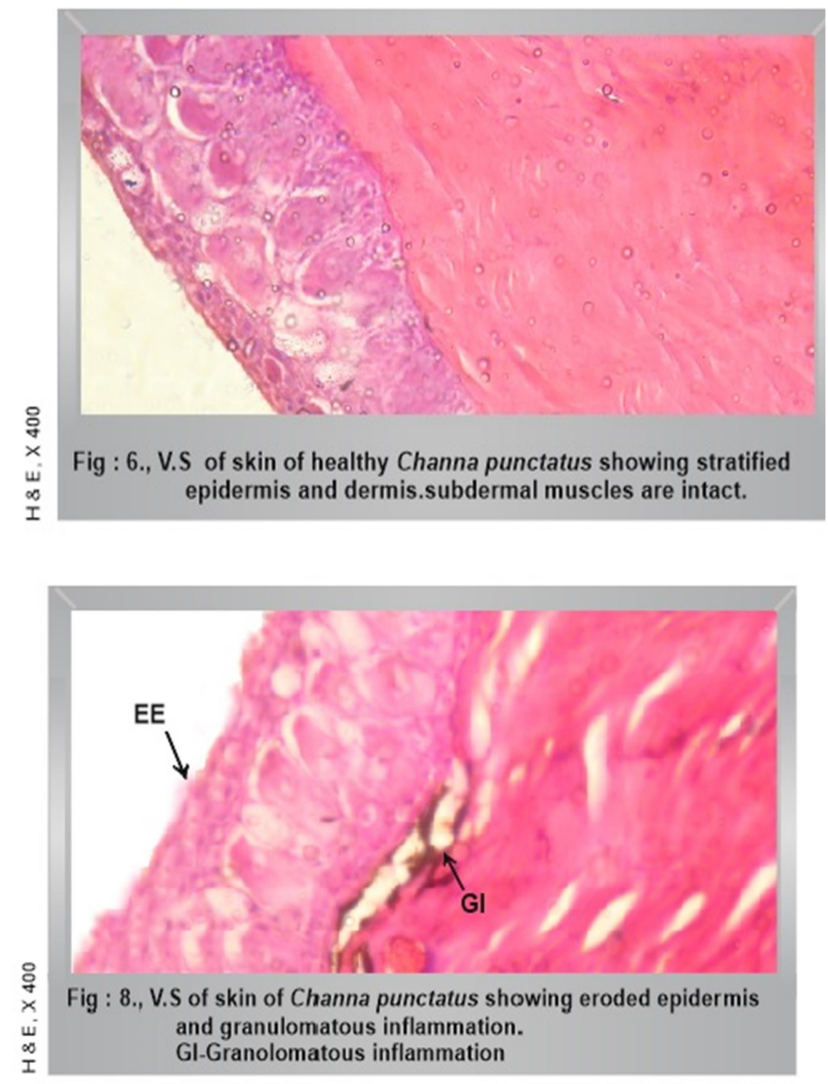

large caseous necrotic areas (Fig:13 and 14).

Histopathological changes in kidney:

In Comparision to the normal structure of T.S. kidney of healthy Channa punctatus (Fig: 15). The kidney of EUS infected fishes exhibited tubular necrosis,interstitial lymphocyte infiltration, haemorrhage (Fig:16). In EUS affected channa, shrinkage of the glomeruli with a large space between the Bowman's capsule and the glomerulus was also seen (Fig:17) .

Electron Microscopic alterations in EUS affected fishes: Electron Microscopic study was carried out in naturally EUS affected fishes, showing heavy Parvovirus (DNA virus) infection at an area of red spot in Channa punctatus (Fig :18)

The EM structure of hepatic cell of naturally affected Channa punctatus showed damage and breakdown of mitochondria and distortion of endoplasmic reticulum (ER), (Fig:19). Chloride cell of gill of EUS affected Channa punctatus showed infection of Parvoviruses (DNA virus) distorted nucleus and disintegration of mitochondria (Fig: 20).
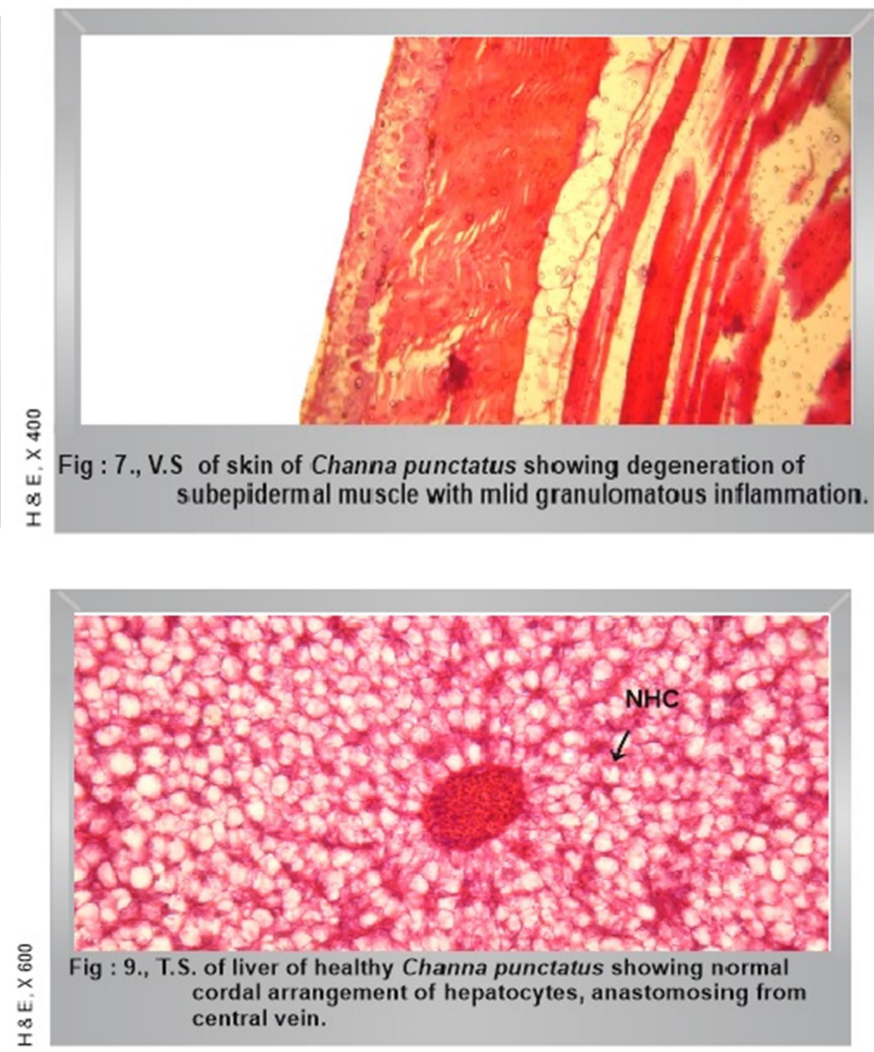


\section{Laharia and Patel}
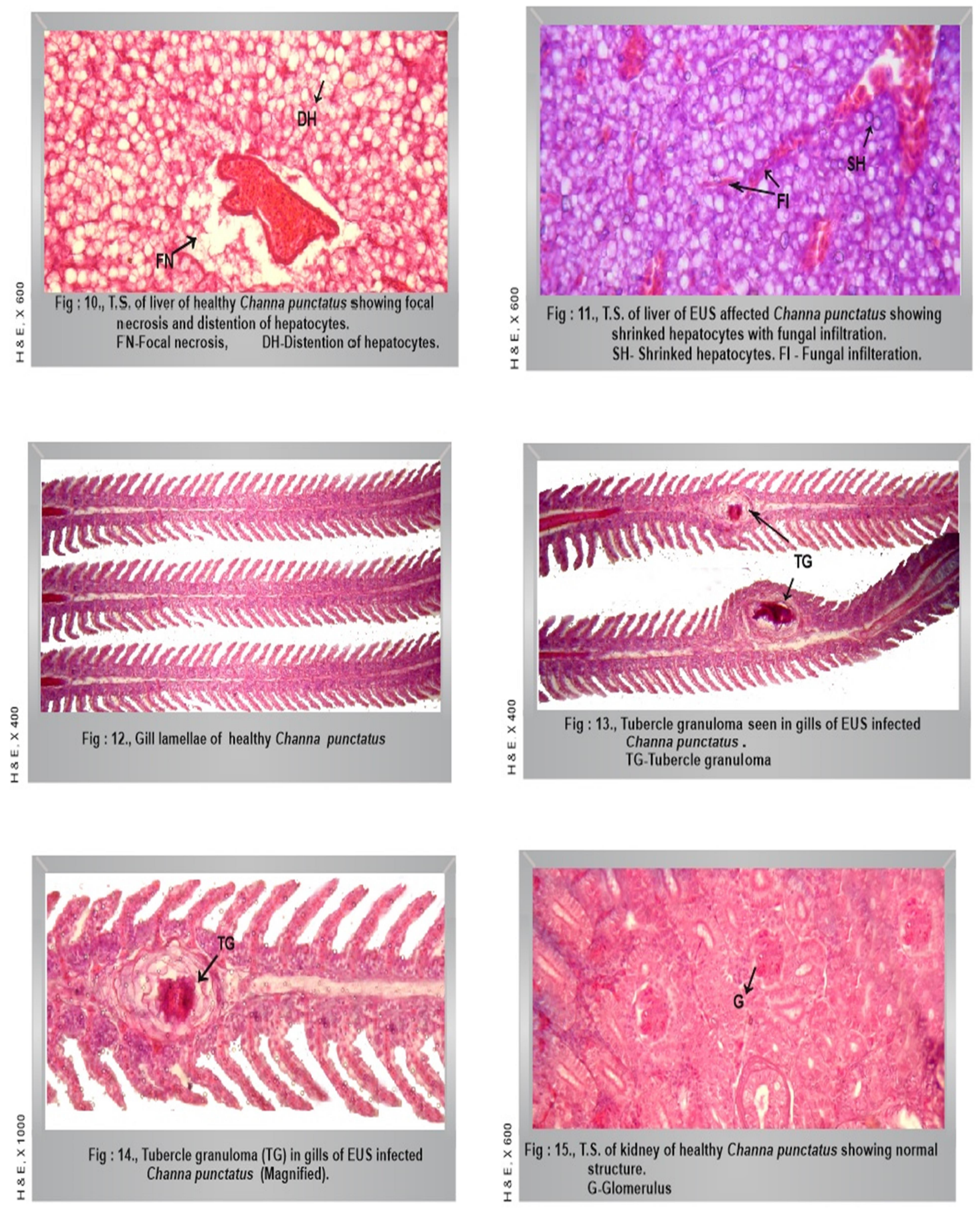

80

Environment Conservation Journal

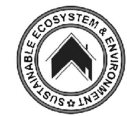



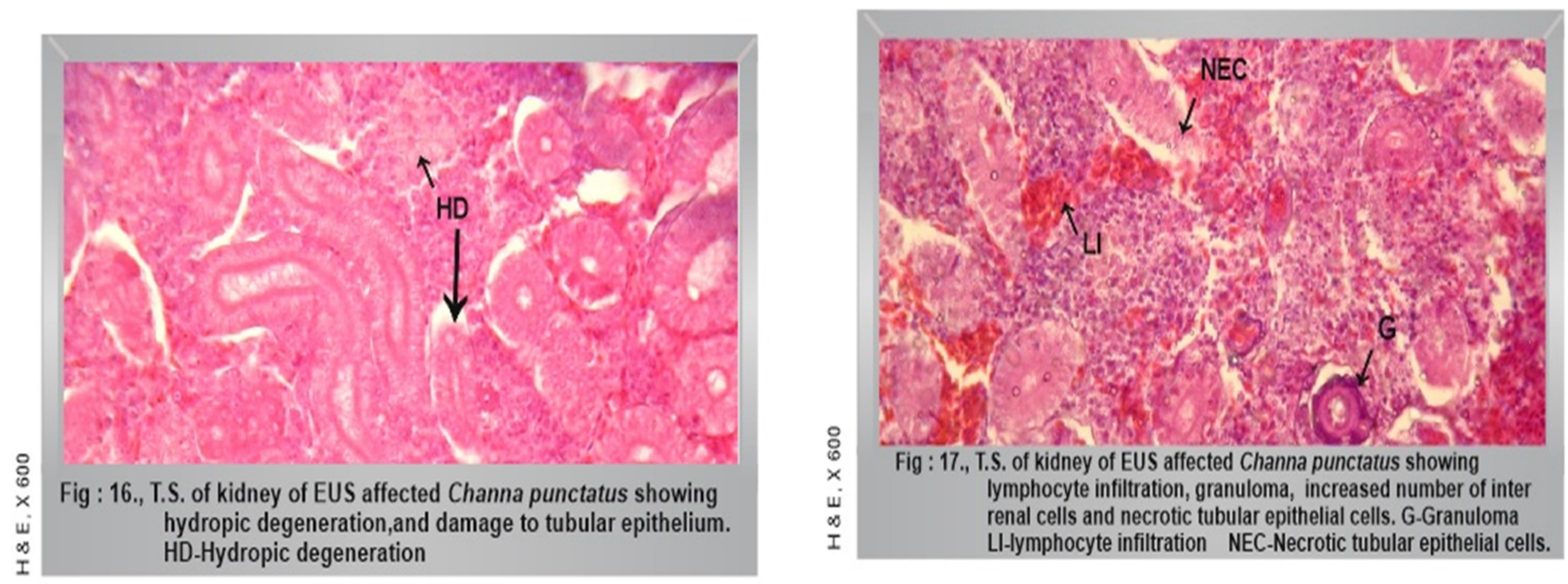

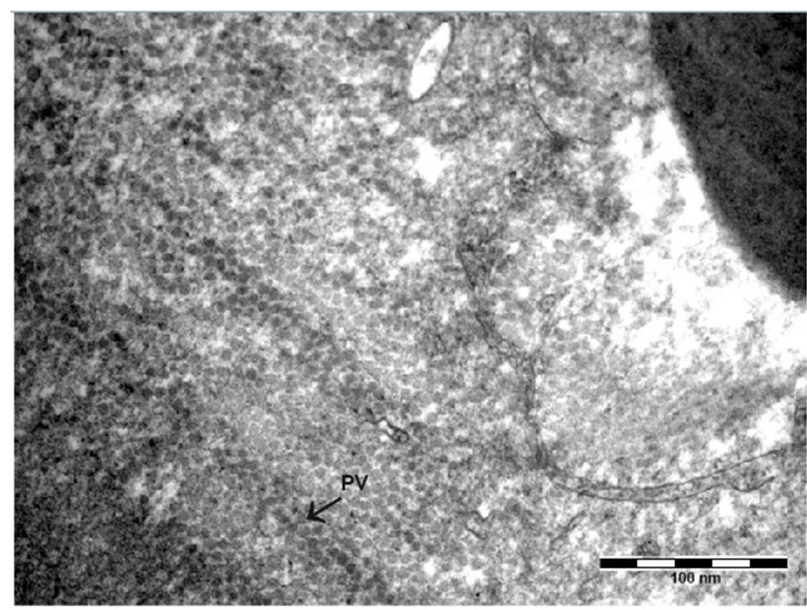

Fig: 18., EM showing heavy viral infection in the skin of Channa punctatus at an area near red spot showing Parvoviruses (DNA virus). PV-Parvovirus

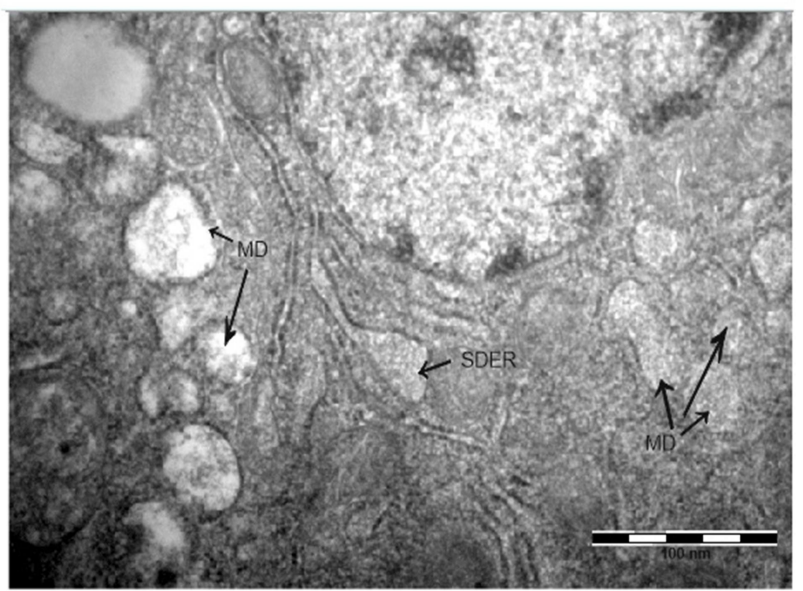

Fig: 19., Electron Microscopic image of a hepatic cell of EUS affected Channa punctatus showing mitochondrial damage and swelling and distorsion of endoplasmic reticulum.

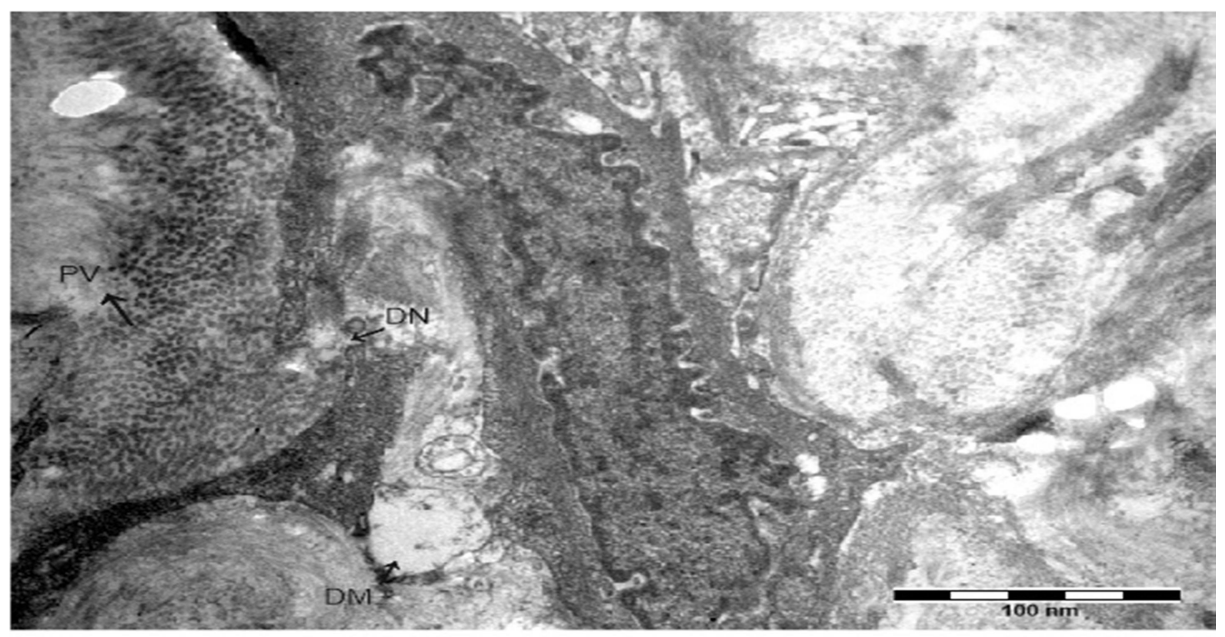

Fig: 20., EM showing heavy viral infection in the chloride cell of gill of EUS affected Channa punctatus showing Parvoviruses (DNA virus), distorted nucleus, and disintegration of mitochondria. DN-Distorted nucleus, DM-Disintegration of mitochondria, PV-Parvoviruses. 
Ulcers are characterized histomorphologically by the consistent presence of deeply penetrating fungal hyphae, extensive myodegeneration and a special type of host cellular defensive response called granulomatous inflammation directed by the fungal agent (Dykstra et al.,1989; Blazer et al.,1999; Vogelbein et al., 2001). This type of response is typically elicitated in vertebrates by infections that are difficult for a host to kill and degrade and is composed predominantly of a mononuclear phagocyte called the macrophage (Cheville, 1983). These cells accumulate within the infected tissues and organize into discrete structures called granulomas that effectively encapsulate the foreign invader. This special type of inflammatory response developed over an attempt by the host to bring to bear a suite of toxic and cytolytic substances produced by the macrophages and designed to inactivate, kill and degrade the infectious agent.

Histopathological findings of the present study strongly agree with the definition and diagnostic features of EUS as proposed in the ODA regional seminar on EUS (Roberts et al., 1994). Histopathological results clearly and consistently show that a specific type of broad, non-septate fungus involved in all EUS affected fish species. Chronic inflammatory tissue surrounding the fungal hyphae to form massive epitheloid granulomas was particularly evident in either gills (Fig:13 and 14) or skin (Fig: 8) of the fish specimens studied.

\section{Conclusion}

Histological studies of the skin of EUS infected channa showed initial epidermal loss exposing the dermis, degeneration of muscles with infiltration of mixed inflammatory cells with deep penetrating of fungal hyphae into the body muscles. As well as in the liver cells. In advanced stage of the disease, the hepatic cells appeared shrinked with fungal infiltration. In EUS infected Channa punctatus, a well developed encapsulated granuloma in the gill lamellae was developed which appeared nodular with characteristic focal grannular granulomas. These were composed of a diffuse distribution of reticular endothelial cells and macrophages.The kidney of EUS affected fishes exhibited tubular necrosis, interstitial lymphocyte infiltration, haemorrhage and well developed inter-renal tissue. Glomeruli appeared shrinked.

In all the electron microscopic observations, the tissue cells of EUS affected fishes showed viruses like Parvovirus even at a red spot stage. Distortion of endoplasmic reticulum and breakdown of mitochondrial cristae were the common observations. In EUS infected Channa punctatus, a well developed encapsulated granuloma in the gill lamellae and and presence of viruses like Parvovirus even at a red spot stage of EUS affected fishes was seen, thus, from the histological observations, it can be said that release of pollutants in the nature are affecting the basic environmental parameters like temperature, salinity, $\mathrm{DO}$ and $\mathrm{pH}$ affecting the protective mucus layer of the fishes making them vulnerable to the attack of virus being crystalline in nature and have cellular penetrating power, followed by bacterial and fungal infection causing more damage to fish tissue leading to ulcers (EUS) ultimately death of the fish (Economic loss) a Loss to aquatic biodiversity, irreversible ecological damage

\section{Acknowledgements}

The authors pay their gratitude to their guide late Dr. G.N.Vankhede. They are also thankful to the department of Central Instrumentation Centre S.G.B.A.U. for providing facility to take photographs of histopathology and also to department of Transmission Electon Microscopy, AIIMS, New Delhi for the photography of viral infections.

\section{References}

Baldock, F.C., Blazer, V., Callinan, R.B., Hatai, K., Karunasagar, I. \& Mohan, C.V., 2005. Outcomes of a short expert consultation on epizootic ulcerative syndrome (EUS): re-examination of causal factors, case definition and nomenclature. In P. Walker, R. Lester \& M.G. Bondad-Reantaso, eds. Diseases in Asian aquaculture $V$. Manila, Fish Health Section, Asian Fisheries Society, pp. $555-585$.

Blazer, V. S.; Vogelbein ,W. K.; Densmore, C.; Zwerner, D E.; May, E. B., 1999. Aphanomyces as a cause of ulcerative skin lesions in menhaden from Chesapeake Bay. J.Aquat. Anim. Health, Vol.1, pp. 340-349.

Cheville, N., 1983. Cell Pathology, 2nd ed. Ames, IA-Iowa State University Press. 


\section{Histological changes in skin and gill of fresh water EUS infected fish}

Choongo, K., Hang'ombe, B., Samui, K.L., Syachaba, M., Phiri, H. \& Maguswi, C., 2009. Environmental and climatic factors associated with epizootic ulcerative syndrome (EUS) in fish from the Zambezi floodplains, the Republic of Zambia. Bulletin of Environmental Contamination and Toxicology, Vol. 83, pp. 474-478.

Dykstra, M. J.; Levine, J. F.; Noga, E. J.; Hawkins, J. H.; Gerdes, P.; Hargis, W.J Jr.; Grier, W. H. and Te Strake, D., 1989. Ulcerative mycosis : A serious Menhaden disease of the South-Eastern coastal fisheries of the United States. Journal of Fish Diseases, Vol. 2, pp. 175-178.

Hasan M.A., M. Mamnur Rashid*, M.A. Islam, K. Mostafa and M. Tarikul Islam., 2008. Histopathological studies of EUS affected shing, Heteropneustes fossilis (Bloch) from a fish farm of Mymensingh, Bangladesh Bangladesh J. Fish. Res., Vol.12, No.1, pp. 21-26.

Kanchanakhan, S., 1996. Epizootic Ulcerative Syndrome (EUS) : a new look at the old story . AAHRI Bangkok Newsletter; Vol. 5, No.1, pp. 2.

Kanchanakhan, S.; Saduakdee, U. and Areerat, S., 1998. Virus Isolation from Epizootic Ulcerative Syndrome-Diseased Fishes. The AAHRI Newsletter Abstracts; December, 1998., Vol.7 , No.2.

Kane, A. S.; Dykstra, M. J.; Noga. E. J.; Reimschuessel, R.; Baya, A.; Driscoll, C.; Paerl, H. W. and Landsberg, J., 2000. Etiologies, observations and reporting of estuarine finfish lesions. Marine Environmental Research, Vol. 50, pp. 473-477.

Lio-Po, G. D.; Albright, L. J.; Michael, C. and Leano, E. M., 1998. Experimental induction of lesions in snakeheads (Ophicephalus striatus) and catfish, Clarias batrachus with Aeromonas hydrophila. Aquaspirillum sp., Pseudomonas sp. and streptococuss sp. J. Appl. Ichthyol., Vol.14, No.1 and 2, pp. 75-79.

Roberts, R. J.; Campbell, B. and Macrae, J. H., 1994. Proceeding of the regional seminar on epizootic ulcerative syndrome. The Aquatic Animal Health Research Institute. Bangkok, January, pp. $25-27$.

Sammut, J.; White, I. and Melville, M. D.,1996. Acidification of an estuarine tributary in eastern Australia due to drainage of acid sulfate soils. Marine and Freshwater Research; Vol. 47, No 5, pp. $669-684$.

Songe, M.M., Hang'ombe, M.B., Phiri, H., Mwase, M., Choongo, K., Van der Waal, B., Kanchanakhan, S., Reantaso, M.B. \& Subasinghe R.P., 2012. Field observations of fish species susceptible to epizootic ulcerative syndrome in the Zambezi River basin in Sesheke District of Zambia. Tropical Animal Health \& Production, Vol. 44, pp. 179-183. (also available at DOI 10.1007/s11250-011- 9906-1).

Viswanath, T. S.; Mohan, C. V. and Shankar, K. M., 1997. Clinical and histopathological characterization of different types of lesions associated with Epizootic Ulcerative Syndrome (EUS). Journal of Aquaculture in the Tropics.; Vol. 12 , No. 1, pp. $35-42$.

Vogelbein, W. K.; Shields, J. D.; Has, L. W.; Reece, K. S. and Zwerner, D. E., 2001. Skin Ulcers in Estuarine Fishes : A Comparative Pathological Evaluation of Wild and laboratory-Exposed Fish. Environmental Health Perspectives. Vol. 109:,suplement 5, pp. 687-693.

Weissman, K., 1972. General zoological microtechniques. Pub., Blkiston Company, Philadelphia, pp. 22. 


\section{The probable path of EUS}

\section{Post rainy season}

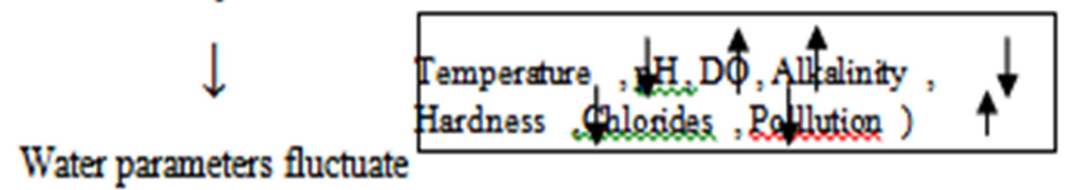

Water parameters fluctuate

\section{Hardness dolocidas, Pallution )}

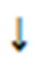

Stressed fish

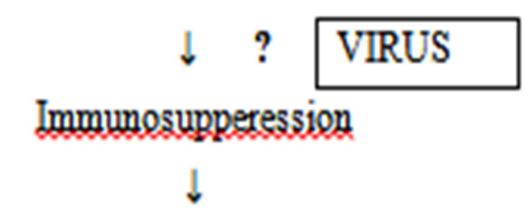

Loss of mucus and scales

Red spot appear on the body at the point of infection

Scale loss, degeneration of epidermis with exposure of

dermis, inflammation and appearence of ring

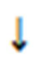

Bacteria and fungi invade deeper in fish tissue

Tissue necrosis, Muscle necrosis, infilteration of Lymphocytes,

Granulomatous growth, Antigen - Antibody reactions, Proliferation of

lymphocytes leads to more damage to fish tissue leading to ulcers (EUS)

Death of the fish (Economic loss)

\section{$\downarrow$}

Loss to aquatic biodiversity

irreversible ecological damage 